\title{
The Potential Role of Women in Contributing to Countering Ideological Support for Terrorism: The Cases of Bosnia and Afghanistan
}

\author{
Frances Pilch*
}

\section{Introduction}

We should make no mistake: This struggle between religious forms, between prescriptive, repressive doctrine and the sublime adventure of faith, is one of the two great strategic issues of our time-along with the redefinition of the socio-economic roles of women, their transition from being the property of men to being equal partners with men (which is the most profound social development in human history). ${ }^{1}$

One of the most-discussed topics in the fields of international relations and security studies at present is how Western governments can best work to counter ideological support for terrorism. The military action in Afghanistan that brought down the Taliban regime was essential and effective (at least in the short term); terrorist financial networks have been disrupted; and increased intelligence capacity has undoubtedly been developed. However, there is widespread consensus that we have not done well in countering terrorist ideology, which is what fuels recruits to join terrorist movements. Brian Michael Jenkins, one of the world's leading authorities on terrorism, has said, "[w]e cannot ignore the social phenomena and dynamic processes that turn young men like the London bombers into suicidal jihadists ... otherwise, even as we succeed in degrading the terrorists' operational capabilities, their ideology will spread and their base will grow. Here, I think, we have not done well."2

The central thesis of this essay is that there is a link between terrorism and issues concerning women's rights; and that, therefore, when women's rights are advanced, the ideological structures that provide support for terrorism can be subtly undermined. The importance of women's voices and issues, therefore, should not be overlooked, and the concerns of women should be addressed as a critical part of any effort to counter terrorist ideology.

The struggle for women's rights takes many forms and is fought on many fronts. The actors in this struggle are also many and varied, including human rights groups, committed individual activists, women's groups within countries, agents of interna-

* Dr. Frances Pilch is a Professor of Political Science at the United States Air Force Academy in Colorado Springs, CO. The views expressed in this paper are solely those of the author and should not be attributed to the U.S. Air Force Academy or the Department of Defense.

1 Ralph Peters, “Rolling Back Radical Islam,” Parameters (2002): 6.

2 Brian Michael Jenkins, “Global Terrorism: Taking the Long View,” Worldviews for the $21^{\text {st }}$ Century 3:3 (Fall 2005): 10. 
tional organizations, and women's groups that have an international reach. The agendas for all of these actors are also diverse-some are primarily interested in preventing violence against women, some advocate for greater socioeconomic freedoms for women, and others are primarily interested in promoting women's political participation. Women have been extremely important in dialogues concerning the peaceful resolution of international conflict and in supporting international initiatives on women's rights. Recognizing the diverse nature of both the actors and agendas in the struggle for women's human rights, this article seeks to encourage the inclusion of women's voices and interests in the discourse on terrorism.

Historically there has been a critical and undeniable link between radical Islamic fundamentalism and terrorism. ${ }^{3}$ Radical Islamist regimes such as the Taliban in Afghanistan have harbored and sometimes encouraged terrorists. It is no accident that the northwestern provinces of Pakistan, in which Islamic fundamentalists operate with virtual impunity beyond the reach of the central government, are home to remaining $\mathrm{Al}$ Qaeda cells; nor is it a coincidence that such cells flourish along the coast of Somalia, where there has been a revival of fundamentalism in the chaos surrounding the failure of the Somali state. In these areas_areas in which Islamic fundamentalism either holds sway or is rising in importance-women's rights are often severely restricted and increasingly jeopardized.

Although radical Islamic fundamentalism is not the same thing as terrorism, there is a link between the two. Therefore, when women are mobilized to advance their rights, they may be, at the same time, perhaps even without their knowing it, advancing the fight against terrorism. In addition, women everywhere suffer from chaos and violence; they lose brothers, fathers, husbands, and children in violence perpetrated by terrorists. Women are the victims of regimes and cultural systems that do not permit them to have a voice, or even to have recourse to the law for redress of their grievances. Therefore, if we seek to undermine the ideology of terrorism in the name of promoting the rights of women, we must examine policies that tend to support regimes that habitually repress women. Additionally, when permitted to be part of the political process, women have been powerful advocates for peace, reconciliation, and moderation. Therefore, those who wish to address the ideology of terrorism would be wise to address as well the importance of women's issues and concerns.

While many policy-makers tend to think in terms of states and their actions and initiatives, in fact much of the change that is taking place in the world can be credited to the increased reach and dynamism of non-governmental organizations. These organizations have power that is seldom sufficiently recognized. Messages can be circulated worldwide in a matter of seconds; resources can be shared between groups in remote corners of nations on different continents; a group in one part of the world can model

3 Belinda Cooper and Isabel Traugott, “Women's Rights and Security in Central Asia,” World Policy Journal 20:1 (Spring 2003): 62. Cooper and Traugott write that "women make up what might be called a ready-made antiterrorist potential. While it is certainly wrong to equate all fundamentalism with terrorism, terrorism today is closely linked with religious fundamentalism.” 
its message and behavior on that of a group in another part of the world; and women, who may have once lived and worked in isolation, can find support for their dreams and ideals as never before.

Much of the work of organizations such as the United Nations High Commission on Refugees is actually carried out by non-governmental organizations. ${ }^{4}$ Humanitarian missions worldwide depend on NGOs for specialized help. They are partners in every meaningful way in advancing the interests and well-being of the most vulnerable members of global society. Therefore, it is vital that efforts to counter terrorist ideology become aware of the potential of NGOs that address women's issues to act as potential vehicles of change and reform within the Muslim world.

\section{Diversity Within the Muslim World and the Women's Movement}

A powerful consideration about how best to involve women in countering the ideologies that support terrorism deals with the tendency to view women in the Muslim world as a monolith, or in the aggregate, as if they all had the same perspectives and problems. As Saimah Ashraf has written, "Many people don't realize ... that there are a large variety of Muslim women around the world, living in such diverse areas as the Middle East, South Asia, South East Asia, Yugoslavia, Northern Africa, and the Southern parts of the former USSR...." ${ }^{5}$ Political and cultural orientations toward women and the level of economic and social development within these areas vary widely. Additionally, there are many different interpretations of the meaning of the Koran within Islam itself, with significant variations across sects and regions.

One of the more interesting developments within the Islamic community concerns the relationship of the Koran to the modern world. ${ }^{6}$ Women have joined in this conversation, with some seeking to return to the earlier portions of the sacred text, which tend to be more tolerant and liberal, and some seeking to reformulate conservative approaches to women's roles in light of the history of Muhammad and his life. Saimah Ashraf makes a strong case for the original understanding of Islam, in which women had privileges and in which there were no double standards: "However, with the progression of time, the rights of Muslim women began deteriorating, and today, very few Muslim countries adhere to the Islamic ideal in their treatment of women."7

4 Author's interview with Dan Conway, former Human Resources Director for UNHCR, 10 November 2006.

5 Saimah Ashraf, "Shattering Illusions-Western Conceptions of Muslim Women," available at www.islamfortoday.com/shatteringillusions.htm.

6 For example, see the work of Abeer A. Ibrahim, visiting scholar at the University of Colorado, Colorado Springs, especially her forthcoming book, Honor Behind the Veil; Representing Women in Islam, in which she argues that faulty interpretations of the Koran that are detrimental to women's rights have been advanced by fundamentalists. Author's interview with Abeer A. Ibrahim, 14 December 2006.

7 Ashraf, "Shattering Illusions." 
It is absolutely essential that one realize that the role of women varies significantly across different states and societies. ${ }^{8}$ The status of women and women's groups is completely different in Tunisia and Turkey than it is in Saudi Arabia and Egypt. In Algeria, activist women's groups have flourished, while in Egypt, where women enjoy progressive access to education, some women's groups have been shut down and their leaders arrested. No culture is static; political and religious forces within a country can change, altering perceptions of the roles of women and limiting or increasing women's access to legal remedies, education, and social advancement. Women's movements themselves are quite different as well, and utilize disparate theoretical frameworks and tools. However, in almost all Arab countries, the legal status of women and the nature of family laws, or "personal status codes," is an enduring issue that promotes contentious debate.

In an occasional paper published by the United Nations Development Program, Valentine Moghadam notes that "all Arab countries have in place family laws-also known as personal status codes - that confer upon women the status of dependent and minor with respect to marriage, divorce, child custody, and inheritance.... The cumulative effect is gender-based discrimination and second-class citizenship for women...." Moghadam notes that, since the 1980s, questions concerning the role of women in society have become highly politicized, and that the conservative Islamic revival has brought into question the idea of Western conceptions of human rights that emphasize autonomy and choice, and has suggested in some cases instead the idea of "Islamic" women's rights, with "an emphasis on respect for family, religion, and community." 10 The idea of the "Western woman" may be deeply linked with the idea of Western cultural imperialism, and may be viewed as an attack on Islamic culture itself. $^{11}$

Some women's rights advocates in the Middle East have reacted to religious laws and cultural practices that restrict women's freedom of choice in society by condemning Islamic "fundamentalism." However, it is important to note that there are interesting differences within feminist movements located in Islamic society. One of the principle arguments one might see, for example, is that Islam itself is not inherently mi-

8 This point was stressed at a panel addressing "Women, Human Rights, and Islam: Exploring the Complexities,” held by Amnesty International in 2000. A summary is available online at www.amnestyusa.org/events/agm/agm2000/islam.html.

9 The single best source for information on women's activism in the Muslim world is the occasional paper by Valentine M. Moghadam, "Towards Gender Equality in the Arab/Middle East Region: Islam, Culture, and Feminist Activism,” published by the Human Development Report Office of UNDP, and available online at http://hdr.undp.org/docs/publications/ background_papers/2004/HDR2004_Valentine_Moghadam.pdf.

Ibid., 2.

11 Denis MacEoin, “Why Do Muslims Execute Innocent People,” Middle East Quarterly 13:4 (Fall 2006): 6. The radicalized, jihadist type of Salafi thought and activism was advanced by Sayyid Qutb (1906-66), one of the most influential Muslim theorists. He says that true Muslims should fight the forces of modernity. His thinking is echoed today by Osama bin Laden and the Afghan Taliban. 
sogynist, and that in fact, in the early days of Islam, women played a much greater role in society and in religion. The noted scholar Assam Afsaruddin takes this view, asserting that Islamic "modernists" believe that the Islamic moral/legal code can be interpreted within a general ethical framework. She notes that the sharia is not all-encompassing, but rather provides broad guidelines for conduct rather than specific prescriptions. She also notes that in the Islamic tradition there is to be found divine sanction for religious and cultural pluralism. Most importantly, regarding women's issues, she notes that women were politically enfranchised in the seventh century under early Islam. ${ }^{12}$ Therefore, within the Muslim world, you will find those who believe that women's rights can be interpreted within the text of the Koran, and perhaps even within the context of Islamic resurgence, and you will also find those that hold a different viewthat is, that women's progress in the Islamic world is dependent upon cultural change, education, and the institution of new legal protections. According to Moghadam, "Islamic feminism is a Koran-centered reform movement by Muslim women with the linguistic and theological knowledge to challenge patriarchal interpretations and offer alternative readings in pursuit of women's advancement and in refutation of Western stereotypes and Islamist orthodoxy alike." ${ }^{\prime 3}$

Some Islamic feminists agree that women's status in Muslim societies is inferior, but attribute that to the development of a highly patriarchal society-with its corresponding male-dominated structures of power-rather than to Islam itself. Many of these modern Islamic feminists "are aware of what may be called global feminism and many have attended international women's conferences, but they are keen to make their case for women's rights within a religious idiom." ${ }^{14}$ To these, the priority that is given to the human individual in Western society may not resonate within their culture, which places high value on the maintenance of family and community. An example of this kind of thinking can be found in an interview with Ingrid Mattson, the first female to head the Islamic Society of North America. When asked what the term Muslim feminism means to her, she replied, "Feminism — the idea that women have rights, that women and men should exert themselves to ensure that women have a meaningful way to achieve their rights-is a good concept. But it shouldn't be a defining worldview. My agenda is not a narrow one of only looking at the interests of women. I'm looking at the interests of our whole community." 15 Secular feminists, on the other hand, frame

12 From a lecture by Asma Afsaruddin, "Islamic Perspectives on Democratic Virtues, Pluralism and the Common Good," at the Carnegie Endowment for International Peace, Washington, D.C., 26 July 2006.

13 Moghadam, "Towards Gender Equality in the Arab/Middle East Region," 12.

14 Ibid., 13.

15 Dilshad D. Ali, interview with Ingrid Mattson, n.d., 2006; available at www.beliefnet.com/ story/198/story_19898.html. 
the debate in terms of international conventions and the global discourse, and tend to talk in terms of democratization and human rights in general. ${ }^{16}$

Some scholars feel that the Western feminist movement has been derelict in appropriately addressing women's issues in the Muslim world. As Kay Hymowitz has written, "few quarrel with feminism's core moral insight, which changed the lives (and minds) of women forever: that women are due the same rights and dignity as men. So, as news of the appalling miseries of women in the Islamic world has piled up, where are the feminists? Where's the outrage?"17 Hymowitz talks about the three manifestations of current feminism: gender feminism, multiculturalism, and world-government utopian, the closest to classical liberal feminism. The question Hymowitz astutely poses is whether any of these strains of feminism is "interested in freeing women to make their own choices...."18

The debate concerning differing perspectives on women's issues within or outside an Islamic framework has been clearly evident in Iraq. Following a major effort by women's rights activists to prevent the adoption of sharia under the provisional government, U.S. representative Paul Bremer worked hard to establish a secular interpretation of the relationship between religion and state. However, provisions concerning a legal regime in Iraq proved to be a major battleground between various interpretations of the role of Islam as the new constitution was debated. While sharia was not adopted wholesale, the compromise that ensued generated the new provision that no law can be passed that contradicts the "established rulings" of Islam. This may prove to be a major setback to the advancement of women in Iraq. The question is, of course, who will determine what those "established rulings" are-that is, who will be the interpreters of what the Koran is intended to mean today. ${ }^{19}$

In many Muslim states, the development of the apparatus of the state has meant compromise with religious elites. Therefore, one must be conscious of different "domains" of women's rights. The "public domain" concerns women's right to vote, to hold jobs of their own choosing, to be educated, and to serve in elective office. These areas in general are somewhat more easily implemented that those matters pertaining to family law, which have typically been the preserve of religious elites. For example, while Gamal Abdel Nasser in Egypt allowed women more access to education and employment in the 1950s and 1960s, his regime could not address family matters. ${ }^{20}$ One could interpret this as a clear distinction between the public sphere and the private

16 For an excellent overview of feminist arguments within the Islamic world, see Jasmin Zine, "Between Orientalism and Fundamentalism: The Politics of Muslim Women's Feminist Engagement,” Muslim World Journal of Human Rights 3:1 (2006).

17 Kay S. Hymowitz, "Why Feminism is AWOL on Islam,” City Journal (Winter 2003); available at www.city-journal.org/printable.php?id=985.

18 Ibid., 5.

19 See Isobel Coleman, "Women, Islam, and the New Iraq,” Foreign Affairs 85:1 (Jan.-Feb. 2006).

20 Moghadam, “Towards Gender Equality in the Arab/Middle East Region,” 16. 
sphere. This pattern, while not universal, is quite common in Muslim-dominated countries.

The gravity of the political difficulties of changing family law, or law defining the private sphere, was made evident in Pakistan in the autumn of 2006, when lawmakers from a coalition of six Islamic groups threatened to vacate their parliamentary seats if Pakistan's government were to change a rape law that had been criticized by human rights activists. Such a walkout could potentially have destabilized the government of President Pervez Musharraf. In August, his ruling party had proposed a bill to amend the Hudood Ordinances, Pakistan's religious-based laws governing rape and vice, which were adopted in 1979 after being pushed by a group of Islamic clerics. The move to amend them was initiated to advance protection of women's rights; under the Hudood Ordinances, for example, women who reported being raped had to "produce four male witnesses to the crime, or face charges that they had committed adultery.",21 The new bill was stalled for a considerable length of time before it finally passed the lower house of parliament. However, the clerics and fundamentalists won a different battle on the provincial level in the North West Frontier Province (NWFP). The Hasba bill calls for an accountability bureau, headed by a religious cleric, who is to uphold "Islamic virtues."22

Family laws are often used to justify violence against women, both within the home and in society at large. ${ }^{23}$ "Honor killings" continue to take place in Pakistan and Afghanistan, and are a continuing problem within immigrant communities in Europe. Domestic violence is hidden inside family walls; violence against immigrant women workers in Arab households is a whispered fact of life in Saudi Arabia. Female genital mutilation (FGM) is tacitly condoned in Sudan and Egypt. In a neo-patriarchal state, it is virtually impossible for women to have access to legal remedies when crimes of violence are committed against them. Where fundamentalist forms of Islam have become allied with military or political power, or where clerics have assumed control over the apparatus of the state, political systems "have applied sharia in a harsher form than usual."24

Reflecting the diversity of women's experiences and roles in Islamic states, women in Central Asia were frequently empowered under communist rule, and were able to obtain access to education and jobs. However, after the dissolution of the Soviet Union, many successor regimes, such as that in Uzbekistan, have experienced growing fundamentalist movements within their borders. Scholars such as Belinda Cooper and Isabel Traugott have noted some disturbing trends in this region: "Central Asian

21 David Montero, “Rape Law Reform Roils Pakistan’s Islamists,” Christian Science Monitor (17 November 2006); available at www.csmonitor.com/2006/1117/p07s02-wosc.html.

22 Ibid. See also Ashraf Khan, “After TV Series, Pakistan Rethinks Rape, Sex Laws,” Christian Science Monitor (11 July 2006); available at http://www.csmonitor.com/2006/0711/p01s03wosc.html.

23 For an excellent discussion of Islamic law and punishment, see MacEoin, "Why Do Muslims Execute Innocent People.”

24 Ibid., 6. 
women ... have historical reasons to oppose religious extremism.... Yet throughout Central Asia, poverty, political repression, and a resurgence of traditionalism are keeping women out of the fight against terrorism and even pushing them into the arms of fundamentalists."25

\section{Women's Issues and Universal Norms}

In spite of the entrenched patriarchal power structures in many Muslim states, women are slowly becoming more educated, are taking part in worldwide conversations about women's issues through the use of the Internet, are traveling beyond their state boundaries, and are participating in conferences and symposia that address women's rights as human rights. While they may disagree on the relationship of the women's movement to Islam, they tend to unite around certain issues, the most prominent of which is violence against women. In general, women from all cultures seek to prevent the exploitation of women through sexual and other violence, and seek legal protections and remedies for women who are vulnerable to violence. ${ }^{26}$

Arab women were active during regional preparations for the Beijing Women's Conference in 1994. Women's organizations proliferated worldwide after Beijing. In this period women turned their attention to a new range of activities. Moghadam identifies seven types of women's organizations that developed during this period: service organizations; professional associations; women-in-development NGOs; worker-based organizations; research centers, women's studies institutions, etc.; women's auxiliaries of political parties, and; women's rights or feminist organizations. ${ }^{27}$ She notes that, of four common demands, two are directly related to the "private sphere": the "modernization of family laws, and the criminalization of domestic violence and other forms of violence against women."28

In 1999, Human Rights Watch produced a powerful report on violence against women in Pakistan. ${ }^{29}$ The report noted that "estimates of the percentage of women who experience domestic violence in Pakistan range from 70 to upwards of 90 percent."30 The explanations for the violence include rage over inadequate dowries, honor killings, and killings because of alleged sexual liaisons. It is clear that family structure in that country promotes the subordination and vulnerability of women.

The gains that were made by women when the Taliban was overthrown by the United States-led coalition in Afghanistan are even now in danger of being reduced, as the security situation becomes more volatile. Human Rights Watch reports that, while

25 Cooper and Traugott, “Women's Rights and Security in Central Asia,” 59.

26 See, for example, Waheed Khan, "Pakistanis Try Confronting Shame of Honor Killings," Reuters (22 May 2006); available at www.whrnet.org/fundamentalisms/docs/issue-pakistan0606.html. Moghadam, “Towards Gender Equality in the Arab/Middle East Region,” 26. Ibid., 27.

Human Rights Watch, “The Scope of the Problem of Violence Against Women,” HRW Report (1999); available at http://hrw.org/reports/1999/pakistan/Pakhtml-05.htm. Ibid., 1. 
women in general say that life is better now than it was under the Taliban, women's rights advocates have been targeted, sexual assault is common, and violence against women, girls, and boys is "both frequent and almost never reported."31

Although women's groups throughout the world prioritize concerns differently, and frame the debate on women's issues in a variety of ways, there is some consensus that can be discerned. The Universal Declaration of Human Rights, the Convention on the Rights of the Child, the Convention on the Elimination of All Forms of Discrimination against Women, and the Beijing Declaration and Platform for Action all seek to "promote and protect the full enjoyment of all human rights and the fundamental freedoms of all women throughout the life cycle.” Most nations of the world have signed on to these agreements, although some have registered rather serious reservations. Nevertheless, there is some consensus that "women's rights are human rights," and that all states, regardless of their religious composition, should promote these rights. Women's groups can work toward that goal, within their individual perspectives and frameworks. In the Muslim world, this approach is reflected in the work of Islamic reformers, mostly outside the Arab world, who are trying to "bring Islam into closer harmony with universal standards of justice, tolerance, pluralism, and human rights." 32 The feminist scholar Asra Q. Nomani is an example of this school of Islamic reform.

However, other Muslim writers disdain the idea of human rights as defined by the Universal Declaration of Human Rights, saying that these are of Judeo-Christian origin, and that "human rights must be Islamic human rights." 33 To these scholars, "living by the sharia (religious law) is the key both to the moral life and to the regeneration of the Muslim faith., ${ }^{34}$ Most Islamic fundamentalists pursue the twin goals of restoring Islamic laws and values while at the same time attacking and denouncing Western influences. Ana Serafim notes that, "Western values such as individualism, liberalism, human rights, equality, liberty, democracy, free markets, and separation of church and state often have little or no resonance in Islamic culture," and that Islam is a "pervasive religion" that regulates every aspect of human life. ${ }^{35}$

Women's rights might be aided by a gradual recognition on the part of the most repressive states that the economic development and well-being of any state is influenced by the ways in which women are allowed to take part in the economy and polity. Ralph Peters has underscored the importance of women's rights to a Muslim states' economic success, noting that

[t]he West's liberation of women (which has been, to a great degree, their self-liberation in the face of stubborn resistance) is the essential element that renders so many Muslims irreconcilable to us. This particular set of freedoms threatens not only

31 Human Rights Watch, “Human Rights Watch Report on Afghanistan” (2003); available online www.hrw.org/reports/2003/afghanistan0703/6.htm.

MacEoin, "Why Do Muslims Execute Innocent People," 6.

33 Ibid., 7.

34 Ana Serafim, “Terrorism-A Cultural Phenomenon?” Connections: The Quarterly Journal 4:1 (Spring 2005): 63.

35 Ibid., 66-67. 
the Muslim male's religious prejudices, but his central identity. Until it successfully addresses the issue of women's rights—-full rights—-Islam will not compete successfully, in any area, with the West. ${ }^{36}$

Women, networking with each other, can be powerful voices for certain goals. One of these goals concerns violence against women. Another goal concerns violence in general, and an interest in peaceful resolution to conflict. Women in Latin America and Russia-continents apart-have advocated for human rights through mothers' groups; in the Middle East, women from different religions have worked together to promote cultural understanding. Women and children suffer disproportionately during violent conflict; thus, it is in their interest to unite to promote peaceful solutions to disputes.

If women have a deep stake in the resolution of conflict, how then can we understand the recent increase in the number of female suicide bombers? ${ }^{37}$ Explanations for this range from the desire of some women to take part in traditionally male activities to heightened recruitment of women by terrorist groups, perhaps because women arouse less suspicion and may gain more media attention for suicide bombings. As one analysis has noted, "Terrorist groups are persuading some women to view suicide attacks as an obligation to dead, wounded or imprisoned relatives.... Some women see carrying out a suicide attack as a selfless expression of love for their families."38

How does one address the role of women and their voices as an antidote to the ideology of terrorism? Most importantly, as in all conflict resolution, the power of "listening" cannot be underestimated. Western policy-makers cannot assume they know and understand the grievances and concerns of women in societies other than their own. However, all people who desire peaceful resolution of conflict have a powerful tool that can be employed to counter terrorist rhetoric - the robust global network of women's organizations composed of women who care about human rights and women's issues around the world.

It is not the goal of this paper to outline the thousands of different women's groups that are at work around the globe. They are supported by women's advocacy groups within major international organizations, like the United Nations, and major NGOs, like Amnesty International and Human Rights Watch. UNIFEM, a group under the auspices of the United Nations Development Fund, maintains an outstanding website that brings women's groups together from all over the world. ${ }^{39}$ There are groups within localities, regions, and states linked through the Internet to participate in a global conversation on the peaceful resolution of conflict and the advancement of the rights of all people, regardless of race or religion.

Particular women leaders are of special note, as they possess great moral courage in the effort to create a more peaceful and humane world. One such woman is Shirin

36 Peters, “Rolling Back Radical Islam,” 15.

37 For an excellent discussion of women jihadists, see David Cook, "Women Fighting in Jihad," Studies in Conflict and Terrorism 28 (2005): 375-84.

38 Farhana Ali “The Bomber behind the Veil," Baltimore Sun (13 December 2005); available at www.rand.org/commentary/121305BS.htm.

39

See www.unifem.org. 
Ebadi, leader of the Defender of Human Rights Center in Iran. That organization has been declared illegal by the government, even while many within Iran's population hail Ebadi's recognition through her award of the Nobel Peace Prize in 2003-the first ever to a Muslim woman. ${ }^{40}$

Arzu Merali, the director of research for the Islamic Human Rights Commission in the U.K., has written insightfully about the differences between Muslim and secular feminists, who "pity each other," according to the author: "Whether we are Western, Muslim, both or neither, we must wake up to the possibility that what we see as problematic for women is much the same whoever and wherever we are. Plastered over billboards, or banished from view, women are subjugated by patriarchy. Demeaning Islam excludes the voices of Islamic women, and that liberates no one."${ }^{41}$

A recent educational initiative was spurred by an informal group of Muslim women from around the world, who developed a new publication called "Claiming Our Rights: A Manual for Women's Human Rights Education in Muslim Societies.” This manual, which is intended to be a non-threatening introduction to women's human rights useful in many different countries, is designed to promote self-awareness among women. Mahnaz Afkhami, executive director of the Sisterhood is Global Institute, a private organization based in Bethesda, MD, directed the effort to produce the manual, which is being tested in Bangladesh, Jordan, Lebanon, Malaysia, and Uzbekistan. ${ }^{42}$

The Rand Corporation study that looked at women suicide bombers arrived at the same conclusion that I have reached-that "one step that the United States and other nations can take is opening a new dialogue with Muslim women. This would help us better understand their grievances and work with them to make their lives better. The dialogue can begin with Muslim women's groups and institutions around the world."

\section{Women in Peacemaking and Reconstruction}

Women can play a critically important role in peacemaking and reconstruction efforts. While this role was not sufficiently recognized until relatively recently, efforts are underway to ensure that women-who suffer disproportionately during conflict-will be vital partners in reconstruction efforts. Some of the important recommendations of a recent study undertaken by the United States Institute of Peace (USIP) on this issue were that "women have not only the right, but relevant information and knowledge, to

40 See Shirin Ebadi, “Iran: An Open Letter from Shirin Ebadi” (11 August 2006); available from the Women Living Under Muslim Laws website, at http://www.wluml.org/english/ newsfulltxt.shtml?cmd\%5B157\%5D=x-157-541589. Arzu Merali, “They Hate Women Don’t They?” The Guardian (U.K.) (21 June 2002).

42 Barbara Crossette, "Claiming Our Rights: A Manual for Women's Human Rights Education in Muslim Societies,” New York Times (29 December 1996); at www.islamfortoday.com/ womensrights3.htm.

${ }^{43}$ Farhana Ali, "The Bomber Behind the Veil.” 
participate in the design and implementation of programs to re-establish security at regional, national, and local levels." 44

Post-conflict scenarios provide the possibility of transition to political systems that can be more inclusive of many sectors of society, including women. The USIP study advocates the adoption of quota systems during these critical transition periods to guarantee women's political participation in postwar transitions. "In decision-making positions following war, research shows that women are leading efforts to promote good governance by fighting corruption, demanding accountability, and maintaining transparency in activities at national and local levels." 45 Another recommendation made by the USIP report is that, in cases where the United States has a role in helping form transitional governments, a review of existing laws should be undertaken to assess guarantees for gender equality, and support should be provided for efforts to address violence against women, property rights, and equality in citizenship for both genders. ${ }^{46}$

However, transitional post-conflict situations also have potential for destabilization, and may encourage the rise of new political forces that can potentially undermine progress toward women's equality. Afghanistan after the fall of the Taliban is a case in point; while advances have been made in the representation of women in the political process since 2001, Human Rights Watch reported in October 2005 that women in the public sphere were frequently harassed. ${ }^{47}$ Outside the relative security of Kabul, violence against women is on the increase. The warlords that hold power in the provinces were hardly advocates of the rights of women in the past, and now that they are buttressed by Western support, many women fear that the bright future they had envisioned is in jeopardy. ${ }^{48}$ Mariam Rawi notes that " $[\mathrm{t}]$ he war on terrorism has toppled the Taliban regime, but it has not removed religious fundamentalism, which is the main cause of misery for Afghan women. In fact, by bringing the warlords back to power, the U.S. government has replaced one misogynist fundamentalist regime with another." 49

44 Camille Pampell Conaway, "The Role of Women in Stablilzation and Reconstruction," United States Institute of Peace Stabilization and Reconstruction Series, No. 3 (Washington,

45

46

See the Freedom House website for country-by-country reports on democratization in the Islamic world, available at http://freedomhouse.org/template.efm?page=84.

48 Mariam Rawi, "Betrayal (Women in Afghanistan)," New Internationalist Magazine (Jan/Feb 2004), 1. Rawi notes that, a full two years after the downfall of the Taliban, the current government was still unable to protect women. For information on the women's advocacy group, Revolutionary Association of Women of Afghanistan, go to www.rawa.org. See also speech delivered by Mariam Rawi, "Women in Afghanistan Today: Hopes, Achievements, and Challenges,” 27 April 2006; text available on the RAWA website.

49

Rawi, “Betrayal,” 2. 


\section{Case Study: The Role of Women's Advocacy Networks in Addressing Violence against Muslim Women in Bosnia}

Women's groups and other non-governmental organizations with a human rights focus have made significant progress in bringing instances of sexual violence to the attention of the international community, and this case study demonstrates what can be accomplished through solidarity and resolve. In Bosnia, women's advocacy groups researched and documented abuses, urged international aid agencies to pay attention to victims of sexual violence and to formulate plans for dealing with widespread rapes and pregnancies, and pressed tirelessly for justice for victims. In cases before the Ad Hoc Tribunals on the former Yugoslavia and Rwanda, they pushed for indictments to include crimes of sexual violence and provided amicus curiae (friends of the court) briefs. In the debates concerning the Statute of the International Criminal Court and its rules and procedures, NGOs lobbied for important provisions on the legal treatment of sexual violence, forcible pregnancies, and sexual slavery.

The Vienna Conference on Human Rights and the Beijing Conference on Women provided the impetus for the growth and networking of many women's advocacy groups. Modern technology has facilitated communication between activists and groups interested in human rights. Most of the important groups and coalitions of groups are closely intertwined, often sharing expertise and databases. Many of them have well-developed websites and sophisticated e-mail lists. Most work in concert with grass-roots organizations, often worldwide. Their conscientious advocacy, collective expertise, and information and education campaigns have contributed greatly to a genuine revolution in the body of international law dealing with sexual violence. Because so many hundreds of groups are active, only the actions and achievements of a few can be documented here. However, they are representative of a pattern of interest articulation that is truly altering the face of the international system and its conduct of international legal affairs concerning sexual violence. ${ }^{50}$ The involvement of non-state actors in the evolution of international law on sexual violence in terms of the documentation of human rights abuses; contributions to legal indictments, judgments, and interpretations; and the inclusion of a gender-sensitive perspective in the Statute of the International Criminal Court deserve mention.

NGOs have often been in the vanguard of reporting on sexual violence in areas of conflict. Their reports have documented incidences of rape, placed the incidents in the context of the conflicts, and suggested legal interpretations of those crimes. Documentation of crimes of sexual violence has not only raised public consciousness but has also provided invaluable information for criminal investigations. These reports have

50 Scholarly literature on women and human rights and gender issues in international law has greatly expanded knowledge in these areas. See for example, Kelly Dawn Askin and Dorean M. Koenig, Women and International Human Rights Law (Ardsley, NY: Transnational Publishers, 2000); Vesna Nikolic-Ristanovic, Women Violence and War (Budapest: CEU Press, 2000); and Lois Ann Lorentzen and Jennifer Turpin, Women and War Reader (New York: NYU Press, 1998). 
encouraged the international community, through the United Nations, to name "Special Rapporteurs" in many areas of concern. Investigative reports by NGOs are valued as independent assessments of human rights crises. Because organizations such as Human Rights Watch, Medecins Sans Frontieres (Doctors Without Borders), and Amnesty International have excellent working relationships with grass-roots organizations, they are often able to investigate where others fear, or are unable, to tread.

Examination of the testimony before the Commission on Security and Cooperation in Europe in 1993 indicates the importance of NGOs in providing documentation of systematic rape in the former Yugoslavia. ${ }^{51}$ The work of Amnesty International, Helsinki Watch, and the U.S. Committee for Refugees in substantiating claims of widespread rape of women during the conflict in Bosnia-Herzegovina was critical to developing an understanding of the systematic nature of these crimes. Their contributions were noted in several of the Helsinki Commission hearings. In another example of the documentation efforts of NGOs, Physicians for Human Rights, a non-governmental organization, assembled an international team of female physicians under the auspices of the UN Commissioner on Human Rights to investigate reports of widespread rape and other forms of sexual abuse. In addition to documenting instances of rape, the reporting team instituted standard questionnaires for rape victims and argued that the collection of information about rape in war "must be handled by professionals trained to gather legal testimony and to recognize the psychological vulnerability of victims of rape."52

Equality Now is an NGO devoted to the rights of women. Its activist branch, the Women's Action Network, consists of almost 20,000 members in more than one hundred countries around the world. ${ }^{53}$ The Vice-Chairman of the Board of Directors of Equality Now testified before the Commission that she had just returned from BosniaHerzegovina, where she had spoken to "hundreds of survivors of rape camps and concentration camps." She noted that "women are being raped and killed systematically just because they are Muslim." 54 Equality Now was also active in assisting with the Final Report of the UN Commission of Experts, under the direction of Cherif Bassiouni, which preceded the establishment of the ICTY by the UN Security Council. ${ }^{55}$

The investigations into sexual violence in the former Yugoslavia conducted by the European Community noted the use of "a wide variety of interlocutors," including refugee centers and governmental and non-governmental organizations. ${ }^{56}$ Refugee or-

51 The Office on Security and Cooperation in Europe, formerly known as the CSCE, monitors human rights in Europe.

52 CSCE, "Hearing: War Crimes and the Humanitarian Crisis in Former Yugoslavia,” 25 January 1993, 74; transcript available in four parts at www.csce.gov/index.cfm?Fuseaction= UserGroups.Home\&UserGroup_id=58\&CFID=18849146\&CFTOKEN=53.

E-mail to the author from Jessica Neuwirth, President of the Board of Equality Now, 18

March 2001. Equality Now's website is located at www.equalitynow.org.

CSCE, "Hearing: War Crimes and the Humanitarian Crisis," 7.

55

56

Idem. Annex IX of this report dealt specifically with "Rape and Sexual Assault."

Ibid. Appendix. 
ganizations were often critical sources of information. The Women's Commission for Refugee Women and Children, which also led a team to Croatia and Bosnia, issued a report entitled "Balkan Tail of Tears-On the Edge of Catastrophe" that chronicled crimes of violence against women. Frequently, investigation teams would visit refugee centers and interview aid workers and refugees themselves. In the Kosovo crisis, this pattern was repeated. A report on internal displacement in Kosovo and its impact on women and children noted that volunteer physicians working with the displaced were seeing signs of sexual abuse among the refugees, although the women themselves were often reluctant to speak of rape. ${ }^{57}$

As issues affecting women gained attention, several of the human rights NGOs incorporated special "women's rights" units into their organizations. These units have employed very able personnel who have produced some insightful documentation and legal commentary on issues of sexual violence. For example, Human Rights Watch, in cooperation with several other NGOs, corroborated many accounts of rape. The conclusions of their report included grouping rapes into three categories: rapes in women's homes, rapes during flight, and rapes in detention. ${ }^{58}$ The report asserted that Serbian and Yugoslav authorities knew that rape was going on, yet no precautions were taken to prevent further such war crimes. The report noted that the ICTY has jurisdiction over the crimes committed in Kosovo, but that, to that point, no indictments had listed charges relating to the use of rape and other forms of sexual violence as weapons of war. An important contribution of reports such as these has been the clarification of international law concerning sexual violence through a review of recent judgments of the tribunals and other courts on sexual violence. ${ }^{59}$

In addition to providing indispensable documentation of sexual abuse during armed conflict, NGOs have been exceptionally active in providing expert legal interpretation and advice. UN Security Council Resolutions 798 and 820 condemned the reports of "massive, organized, and systematic detention and rape of women" in Bosnia. ${ }^{60}$ These resolutions and media reports of the "rape camps" played a large role in ensuring that rape was included under the jurisdiction of the Statutes of the Ad Hoc Tribunals. The first prosecutor of the tribunals, Justice Richard Goldstone, who was extraordinarily sensitive to issues of sexual violence, noted that "nongovernmental organizations also played a significant role in supporting the work of both the Yugoslavia and Rwanda tribunals. Soon after I arrived in The Hague, I was besieged by thousands of letters and

57 Julie Mertus, "Internal Displacement in Kosovo: The Impact on Women and Children," Women’s Commission for Refugee Women and Children, Occasional Paper (June 1998).

58 Martina E. Vandenberg and Joanne Mariner, "Kosovo: Rape as a Weapon of 'Ethnic Cleansing,'” Human Rights Watch Report 12:3 (D) (March 2000).

59 See, for example, Section V of the Human Rights Watch Report, "International and National Legal Protections against Rape and Other Forms of Sexual Violence,” (2000), 30-34; available at www.hrw.org/reports/2000/fry/Kosov003-04.htm.

60 S/RES/798 (18 December 1992), esp. 1; UN Document S/RES/820 (17 April 1993), esp. paragraph 6. 
petitions signed by people, mostly women, from many countries, urging me to give adequate attention to gender-related war crimes." ${ }^{\prime 1}$

Women's advocacy groups were critical in supporting the inclusion into the Statute of the International Criminal Court crimes of violence against women, including rape as both a "grave breach of the Geneva Conventions" and as a war crime. The strides made by these advocates, within a formidable network of women's advocacy organizations, give us a glimpse into the power of NGOs regarding issues involving women's rights.

\section{Case Study: The Revolutionary Association of the Women of Afghanistan (RAWA)}

The Revolutionary Association of the Women of Afghanistan (RAWA) was founded in 1977 by a woman of only twenty years of age, Meena Keshwar Kamal (usually known as Meena), who articulated the group's goals as “the restoration of democracy, equality for men and women, social justice, and the separation of religion from the affairs of the state." ${ }^{2}$ It started with a group of eleven committed student activists. Ten years after establishing RAWA, Meena was assassinated. In her short time as the visionary leader of RAWA, she campaigned against the Russian intervention, the political regime that supported it, and also against fundamentalist Islamists. A firm proponent of secularism and opponent of foreign intervention, she was instrumental in organizing demonstrations, processions, and meetings to oppose both the Soviets and their supporters and the fundamentalists who eventually replaced them. The cause most important to her was the emancipation of Afghani women and the protection of their rights. She developed a bilingual magazine, Payam-e-Zan ("Women's Message") in 1981, and this magazine continues today as a forceful voice of opposition to the fundamentalist viewpoint. $^{63}$

Meena believed that the future of women in Afghanistan depended upon their access to education, and she established multiple schools for women in her own country and in the refugee camps in Pakistan. ${ }^{64}$ She also helped establish hospitals, clinics, and handicraft centers for refugees through her organization. Because of her opposition to the Soviets, she was invited to represent the Afghan resistance movement at the French

61 Richard J. Goldstone, For Humanity (New Haven, CT: Yale University Press, 2000), 85.

62 Aryn Baker, "Meena," Time Magazine Asia, Special Issue: 60 Years of Asian Heroes (13 November 2006 ); available at www.time.com/time/asia/2006/heroes/in_meena.html. For the best comprehensive history of RAWA, see Anne E. Brodsky, With All Our Strength: The Revolutionary Association of the Women of Afghanistan (New York: Routledge, 2003).

63 See Payam-e-Zan, at http://pz.rawa.org.

64 View from a Grain of Sand, a film directed by Meena Nanji, explores the lives of three Afghani women: a teacher, a doctor, and a social activist. Shot in Afghani refugee camps in Pakistan and in Afghanistan itself, it provides a wealth of information on the history of Afghanistan and its effect on women's issues. One of the featured women, Wajeeha, now a social activist, was rescued by RAWA, who helped her flee to Pakistan and taught her to read and write after her husband was killed fighting the Russians. 
Socialist Party congress in 1981, and she traveled widely in Europe to promote the cause of human rights in Afghanistan. Her assassination was believed to be a result of collaboration between Islamic fundamentalists and the Afghanistan branch of the KGB, known as the KHAD. ${ }^{65}$

RAWA learned an important lesson from the tragic loss of their leader, and after her death RAWA was reorganized into a non-hierarchical structure, with women working in "semi-autonomous committees" with no single leader, but with decision making distributed among many members. ${ }^{66}$ From its original founding group of eleven, RAWA has grown to an active membership of approximately 2,000, although no one knows for sure how many members the group has. Although there are some prominent spokeswomen for RAWA, usually only very close relatives and confidantes will know of a woman's ties to the organization, for it membership is secret. The supporters of RAWA include many men-husbands, brothers, sons, and friends.

After the Soviet Union departed Afghanistan, RAWA continued as a vibrant organization operating in a truly repressive environment. Because of the great danger faced by women activists, RAWA went underground during the period of Taliban rule, and it remains a highly clandestine organization to this day. Schools, orphanages, and nursing courses were operated at great risk by the RAWA cadre, but usually under other auspices. Another of their hallmarks were the secret videos RAWA shot of women being beaten and executed under the Taliban, which were sometimes smuggled to the Western media and shown to publicize the extreme human rights abuses under Taliban rule. ${ }^{67}$

After the U.S.-led war against the Taliban, RAWA continued its activities, attempting to highlight women's issues to the new government and to keep them in the forefront of public dialogue. They also expanded their educational endeavors and began to reach out to potential supporters throughout the world, forging links where appropriate. For example, they established a program for the sponsorship of Afghani orphans through CharityHelp.org. They do not, however, advocate adoption of Afghani children by Westerners, preferring to solicit sponsorships for support of the orphans within their own environment.

For the first time in its history, in September 2006 a RAWA spokesperson appeared on a local Afghan TV channel, debating a hard-line fundamentalist. The group has also sponsored demonstrations and large meetings, most often in Pakistan, but sometimes in Afghanistan. For example, RAWA held a remarkably successful rally to commemorate International Women's Day in Kabul in March 2006.

65 “A Short Biography of Martyred Meena, Founding Leader of RAWA,” available on the RAWA website, http://rawa.org/meena.html.

66 Onnie Wilson, "Revolutionary Association of Women in Afghanistan (RAWA)," available at http://home.vicnet.net.au/ womenweb/actions/Revolutionary Association of Women in Afghanistan (RAWA).htm.

67 RAWA has an excellent website on which these videos and other extensive information about the organization may be found. See www.rawa.org. 
RAWA has achieved worldwide recognition for its activism and commitment to human rights, including the French Republic's Liberty, Equality, Fraternity Human Rights Prize and a Certificate of Special Congressional Recognition from the U.S. Congress in 2004. Members of RAWA have even branched out to fundraising and consciousness-raising events in Los Angeles, and there are subsidiary groups, like the Afghan Women's Mission, based in the U.S., that have strong links to RAWA. It has been featured on Larry King Live and has been promoted by Oprah Winfrey, and it has links with organizations throughout the world.

RAWA is a clear example of an advocacy group that might be perceived as a potential problem for U.S. policy-makers, in that RAWA has been highly critical of the U.S.-led invasion of Afghanistan in 2001 and the situation that has arisen in the aftermath of the invasion. RAWA publicized civilian casualties during the war, and has railed against the collaboration of NATO forces with Northern Alliance leaders, whom they say pose great threats not only to women's rights but also to stability and good governance. ${ }^{68}$ RAWA continuously publicizes its view that Afghanistan is becoming increasingly destabilized, and that the promise of improvements in women's rights after the fall of the Taliban has not been fulfilled. ${ }^{69}$ It therefore is a voice that frequently contradicts U.S. pronouncements that a great victory has been achieved for women in Afghanistan through the NATO intervention. A RAWA statement says that "[o]ne fundamentalist band cannot be fought by siding with and supporting another. In its war on the Taliban and ... Al Qaeda, the U.S. has taken the 'Northern Alliance' into service through wooing and arming certain infamous warlords."70

In June 2006, Amrita Mukherjee Mehmooda, a member of RAWA, offered these remarks in an interview for the Times of India: "Being strongly against the criminal fundamentalist leaders who are seizing the government and by criticizing their supporters and the negative role played by other governments makes [it] hard for RAWA to operate openly."71 And further, "Whenever the fundamentalist terrorists are in power and have key posts in the government, there will be no change in the situation of Afghan women: only a democracy based on secularism can bring some positive changes to the conditions of women. We never expect from the current government with its current composition to help women." ${ }^{\text {,2 }}$ Indeed, women in positions of power are at serious risk in Afghanistan. In September, 2006, Safia Ama Jan, a 64-year-old grandmother, teacher, and provincial director for the Ministry of Women's Affairs, was assassinated in Kandahar, even while she was fully clad in the burqa.

See, for example, RAWA reactions online at www.rawa.org/us-strikes.htm.

See for example, the RAWA report on a gang-rape in Badakhshan, online at www.rawa.org/ gangrape.htm. RAWA, "Let Us Struggle Against War and Fundamentalism,” 22 March 2002; available at www.zmag.org/content/showarticle.cfm?ItemID=1953.

71 "Lifting the Veil: No End to Suffering," Times of India (Calcutta) (24 June 2006); available at www.rawa.org/calcutta.htm.

72 Ibid. 
RAWA has noted that women's security outside of Kabul is perilous, and that warlords consistently brutalize the population, particularly women. A spokesman for RAWA, Mariam Rawi, in a speech in Australia, called attention to the deterioration of women's rights in parts of Afghanistan, saying that "in most parts of Afghanistan women are still banned from going outside their homes unaccompanied, and no education is provided for girls. Because of their continued oppression, a large number of young girls commit suicide, unable to bear the hardships. Tens of self-immolation cases are reported every month in Herat city and its surrounding provinces. Women and young girls are being raped or forced into marriage by the Northern Alliance commanders."73 She went on to say that, under the circumstances, it is "painful to hear some Western leaders and media speak frequently about the 'liberation' of Afghanistan."74 RAWA's unequivocal opposition to the collaboration between the NATO forces and former members of the Northern Alliance, driven by political and military expediency, has put the group frequently at odds with U.S. policy.

RAWA sees the fight for equality for women as part of the universal struggle for human rights and democracy. It advocates nonviolent change, and its programmatic goals include something it calls "economic democracy." Secularism is also extremely important in RAWA's philosophy.

One of its explicit goals is to forge links with other "pro-democracy and prowomen's rights groups nationally and internationally...."75 One of the great successes of RAWA has been in its skillful use of new technology, particularly through its website, which it established in 1996. After the Taliban fell, RAWA continued to try to document human rights violations through photography, reports, and video. As Sonali Kolhatkar has noted, "Digital cameras have made RAWA's documentation much easier and also enabled RAWA to share the images of human rights violations more easily with an international audience...."76 A poignant statement by a RAWA member captures the amazement at the power of new technology: "We never imagined the Internet would bring such a positive result for us. It is very important and something that now we can't imagine we could work without.... At the time I remember it was kind of amazing. The first email from the U.S. that we got, we all called each other to come see this and our eyes were so big....,77

Clearly, RAWA sees a link between its efforts and goals and the fight against terrorism. One of its recent statements urges support of its activities:

Help stop terrorism at its root! By aiding a group of Afghan natives to bring about social change within their country, you can help reshape it into a more peaceful, benign society that will no longer be a haven for globally dangerous extremists. Young boys in RAWA orphanages and schools would otherwise end up in madrasas, where

\footnotetext{
73 Onnie Wilson, "Revolutionary Association of Women in Afghanistan.”

74 Ibid.

75 Sonali Kolhatkar, “RAWA: A Model for Activism and Social Transformation,” 1 June 2006; available at www.rawa.org/sonali-model.htm. Ibid.

77 Ibid.
} 
they would learn to hate women and the West, and learn only about the Koran and how to use weapons! ${ }^{78}$

RAWA is markedly opposed to foreign domination of Afghanistan, and hence has been, from the beginning, outspokenly critical of U.S. policy. Some critics of RAWA have branded the group "Maoist," a charge that was answered in a RAWA statement that stressed the prioritization of its goals - the foremost being the fight against fundamentalists (of all kinds) who would seek to disempower women. ${ }^{79}$

This group is a prime example of an indigenous, grass-roots movement that has arisen from a complex history, therefore espousing a philosophy that is simultaneously anti-fundamentalist, anti-terrorism, non-violent, pro-democratic, anti-imperialist, and anti-interventionist in nature. It has utilized the technology available in this age of globalization to bring about awareness of the plight of women in Afghanistan; it has linked its humanitarian, educational, and health strategies to the future stabilization of its country. At the same time, it has deplored the political expediencies that have brought about what in its view represents a resurgence of fundamentalism, which from RAWA's perspective is the greatest threat of all.

\section{Conclusion: Supporting Women's Initiatives}

The United States and other countries have often focused on democratization and good governance as their primary foreign policy objectives abroad. Invariably, working toward good governance and protection of human rights will involve concerns about the status of women. While these are worthy objectives, there is a fine line to be walked in order to avoid charges of cultural imperialism. In talking about attempts to counter terrorist propaganda and expose the hypocrisies of terrorists, one of the five main policy recommendations emanating from a study conducted at the University of Central Florida includes this statement:

Such support must in most instances be indirect, or else the charges of cultural imperialism will simply enhance the capabilities of terrorists to attract sympathizers and recruits. Governmental and non-governmental programs initiated and conducted by organizations in a given region will be more effective than attempts to impose external values. ${ }^{80}$

One concrete step that can be taken by the U.S. government to influence perceptions of gender equality is to ensure that women are visible in leadership positions

78 “About RAWA,” available at www.rawasb.org/rawa.html.

79 “RAWA's Answer to Nay Thupkaew,” 18 October 2002; available at http://www.rawa.org/ prospect.htm.

80

John Bersia and Stephen Sloan, eds., “A Global Assessment of Terrorism: Perspectives from Current and Future Leaders on Policy, Doctrine and Operational Implications,” Terrorism Studies Program, University of Central Florida and Global Connections Foundation White Paper (11 September 2006), 11; available at http://globalperspectives.cos.ucf.edu/files/ white_paper_09_02_2006.pdf. 
abroad, assigned to missions and as members of negotiating teams. ${ }^{81}$ The United States can also improve visibility of women's issues by continuing to support offices within its agencies and institutions devoted to women's issues. For example, in the Department of State, the Office of International Women's Issues seeks to incorporate gender issues into U.S. foreign policy; at USAID, the Office of Women in Development tries to integrate women's concerns into aid and development programs. ${ }^{82}$ Through the efforts of these organizations, local groups supporting women's rights can often be assisted.

In order to assist grass-roots organizations, accurate information about these groups must be accumulated. Lists of such organizations and influential women leaders should be generated and included in databases, and genuine links with leaders and groups should be sought. Once accurate information has been obtained concerning who the important groups and leaders are, these activists can be invited to conferences and assisted in multiple ways, wherever possible. ${ }^{83}$

Women leaders who advocate reform are often at severe risk. There is probably no issue that is more sensitive within Muslim societies than the issue of women's rights. Where Islamic fundamentalism is experiencing a resurgence, women who have adopted "modern" dress and aspirations are frequently targeted, particularly during periods of transition and chaos. Therefore, security is a fundamental issue surrounding the achievement of women's rights.

Increasingly in Iraq, women activists are being threatened and sometimes killed. As one journalist has written, "There are a lot of women in Iraq who are looking forward to the freedom that Iraq's experiment with democracy promises them. And there are hard-liners who would kill them for it." ${ }^{\text {"4 }}$ The change in the security situation in Iraq has affected women, who did fairly well under the previous Baath Party regime, which advocated equality of women in education and professional development. Now, many women are afraid to leave their homes, and attendance by female students at educational institutions appears to be in decline. ${ }^{85}$ So while governmental transitions provide opportunities for increased inclusion of women in the political process, they may also provide opportunities for the resurgence of Islamic fundamentalism. In the case of Iraq, different regions also have different views concerning women's rights. As civil conflict becomes more and more prevalent, these different perspectives may exacerbate regional and religious tensions.

81 Conaway, “The Role of Women in Stabilization and Reconstruction,” 5.

82 Idem.

83 Camille Conaway notes that lists of international women's groups are maintained by the United Nations Development Fund for Women (UNIFEM), but that local groups need to be recognized as well. See Conaway, "The Role of Women in Stabilization and Reconstruction," 7.

84 Babak Dehghanpisheh, et al., “Iraq’s Hidden War,” Newsweek (7 March 2005).

85 Ibid. 
Women generally have an interest in promoting reform in Muslim societies to enhance their human rights. ${ }^{86}$ As such, they represent an under-valued resource in the fight against terrorism. Cooper and Traugott state that, "in pursuing its antiterrorism efforts, the United States could find long-term support among women, whose interests naturally conflict with those of radically fundamentalist regimes." ${ }^{87}$ Noting that Muslim women in Central Asia might be uniquely positioned to offer such support, they warn that "women in these societies are caught between the repression of the secular regimes in power and the dearth of realistic alternatives other than equally repressive fundamentalist movements." 88

In addition to supporting and building women's organizations, it is critical that the United States attempt to understand the specific concerns of women in their unique cultural and geographic contexts. Programs that enable women to participate in politics at all levels, lending institutions that enable women to improve their economic position in society, and access to education that helps women understand their legal rights should all be critically important objectives of U.S. policy, because they give women tools of empowerment. However, it is quite possible that women's groups will also be opposed to certain aspects of U.S. foreign policy, or may advocate economic policies that are not viewed favorably in the United States. U.S. policy makers should attempt to understand the contexts in which various women's advocacy groups have emerged, and should be careful not to disparage groups solely on the basis that they voice opposition to U.S. policies.

Women of all social classes need secure environments, for it is in the midst of conflict and turmoil that they become the most vulnerable. Domestic violence and violence against women increase dramatically during wartime. In war and in peace, women desire food and shelter for their families and education for their children; if these essentials are provided by religious groups, many of which advocate a fundamentalist outlook, women may develop loyalties toward an anti-Western ideology. Therefore, any approach concerning women and their rights must take into consideration basic human socio-economic rights as well as civil/political rights, the prevention and termination of conflict, and the stabilization of the environment.

Finally, those seeking to combat ideological support for terrorism must recognize that it is far preferable for the impetus for change in Muslim societies to come from within those societies themselves, rather than from external forces. Ana Serafim articulates this as follows: "There is a need for an Islamic Reformation to allow modernization to take place.... This is a battle within Islam itself, rather than between Islam and the West." ${ }^{89}$ The same can be said of the movement for women's rights within the Muslim world. The reinterpretation of Islam by Islamic feminists cannot be dictated by the Western feminist idiom. This is not to say that genuine struggles for women's rights

86 See, for example, John Hughes, “Islamic Women Rise Up,” Christian Science Monitor (29 June 2005); available at www.csmonitor.com/2005/0629/p09s01-cojh.html?s=widep.

89 Serafim, “Terrorism—A Cultural Phenomenon?” 72. 
should not be supported by global NGOs or recognized by Western groups and governments; however, it is important that the West hears the voices of women in an unmediated manner from within the Islamic world, as they articulate their concerns and their vision of fulfilled lives. This can be achieved with the help of the West and international networks of NGOs, but it must ultimately be generated within and sustained by Muslim societies themselves.

The poem, "I'll Never Return,” by Meena, the founder of RAWA, summarizes aptly the idea that women have the potential to emerge as critical voices in the tumult of our century: ${ }^{90}$

I'm the woman who has awoken

I've arisen and become a tempest through the ashes of my burnt children

I've arisen from the rivulets of my brother's blood

My nation's wrath has empowered me

My ruined and burnt villages fill me with hatred against the enemy

Oh compatriot, no longer regard me weak and incapable

My voice has mingled with thousands of arisen women

My fists are clenched with fists of thousands compatriots

To break all these sufferings all these fetters of slavery

I'm the woman who has awoken

I've found my path and will never return.

90 Meena, “I’ll Never Return,” available at www.rawa.org/meena.html. 


\section{THE QUARTERLY JOURNAL}

\section{Bibliography}

Askin, Kelly Dawn, and Dorean M. Koenig. Women and International Human Rights Law. Ardsley, NY: Transnational Publishers, 2000.

Brodsky, Anne E.. With All Our Strength: The Revolutionary Association of the Women of Afghanistan . New York: Routledge, 2003.

Coleman, Isobel. "Women, Islam, and the New Iraq." Foreign Affairs 85, no. 1 (2006).

Cook, David. "Women Fighting in Jihad." Studies in Conflict and Terrorism 28 (2005): 375-84.

Cooper, Belinda, and Isabel Traugott. "Women's Rights and Security in Central Asia."World Policy Journal 20, no. 1 (2003).

Goldstone, Richard J.. For Humanity 2000 . New Haven, CT: Yale University Press, 2000 .

Hughes, John. "Islamic Women Rise Up." Christian Science Monitor (2005).

Hymowitz, Kay S.. "Why Feminism is AWOL on Islam." City Journal (2003).

Jenkins, Brian Michael. "Global Terrorism: Taking the Long View." Worldviews for the 21 st Century 3, no. 3 (2005).

Khan, Ashraf. "After TV Series, Pakistan Rethinks Rape, Sex Laws." Christian Science Monitor (2006).

MacEoin, Denis. "Why Do Muslims Execute Innocent People." Middle East Quarterly 13, no. 4 (2006).

Montero, David. "Rape Law Reform Roils Pakistan's Islamists." Christian Science Monitor (2006).

Peters, Ralph. "Rolling Back Radical Islam." Parameters 6 (2002).

Serafim, Ana. "Terrorism-A Cultural Phenomenon?" Connections: The Quarterly Journal 4, no. 1 (2005): 61-74.

Vandenberg, Martina E., and Joanne Mariner. "Kosovo: Rape as a Weapon of 'Ethnic Cleansing'." Human Rights Watch Report 12, no. 3 (2000).

Zine, Jasmin. "Between Orientalism and Fundamentalism: The Politics of Muslim Women's Feminist Engagement." Muslim World Journal of Human Rights 3, no. 1 (2006). 